\title{
Customer-Centric Transformation of Public Bus Supply in Rural Counties
}

\author{
Florian M. Heinitz ${ }^{1}$
}

Received: 26 September 2015/Accepted: 10 September 2016/Published online: 1 October 2016

(c) Springer International Publishing Switzerland 2016

\begin{abstract}
Taking the perspective of a county administration, this contribution provides the quantity structures to motivate and develop customer-centric adjustment strategies of regional public bus systems, profoundly challenged by the deepening demographic and structural changes in rural parts of Germany. The sharp decrease in travel demand and modal share towards the private car versus the unchanged scope of the network creates a dilemma situation, which was reflected by referring cases of advisory projects. The organization of this paper follows the course of investigation: First, a literature review summarizes the state of discussion of alternative service concepts and financing, including subject-oriented subsidization schemes. In the next step, drivers of operating costs and revenues were formalized in a system of geographic zones in the context of a regional transport supply-demand model—complemented by bus operating costs as well as revenues vs. subsidies in the counties under investigation. The obtained as-is ranges of indicators relevant to the bus operators demonstrate the necessity to offset shrinking patronages in conjunction with adequate cost reductions. The case study results were used to substantiate predictions for the upcoming years under an operating environment scenario of 2025. Based on these findings, market research needs and policy recommendations, operationalized by five proposed implementation projects, were derived.
\end{abstract}

Florian M. Heinitz

heinitz@fh-erfurt.de

1 Transport and Communications Department, Erfurt University of Applied Sciences, Altonaer Strasse 25 99085 Erfurt, Germany
Keywords Public transport - Demographic change $\cdot$ Bus operator $\cdot$ Customer base $\cdot$ Customer-centric

\section{Introduction}

\section{Problem Statement}

The important role of a well-performing public transport supply as a backbone for any non-self-motorized trip chains, the mobility assurance for persons without car availability, the liveability of regions, and also the fulfilment of the ambitious climate protection goals are widely acknowledged. While the market in conurbations-typically featuring rail-bound systems - has developed in a strongly positive way, quite the opposite is true for the public road transport in sparsely populated rural parts of Germany. In structurally less-favoured regions affected by the ongoing socio-demographic change, the provision of a public bus transport has become a particular challenge. Over the past 10 years, the gap between political affirmations and the apparent utilization has been widening. The observed downturn of travel demand is faster than the demographic decline. With an increasingly questionable cost-benefit ratio, the sustainability concern is becoming primarily a financial issue, as changes were procrastinated and deficits are soaring under static public obligations, a given overdeterminacy of cost levels and operational constraints enforced by stakeholders, and fare systems politically prescribed.

The situation of the local passenger road transport in Germany was coined over decades by (i) the prevailing federal legislation (legally binding without any exception also for rural transport networks) and (ii) the federal statespecific organizational/funding principles. Two-tier structures (political level versus operators) and three-tier 
structures (political, coordination level, operator level) are the most common organizational models. Intermediate administration on behalf of the federal state governments complements the model as regulatory body. Its role is to monitor the compliance with standards, approve regional tariffs, and distribute compensatory funds.

In rural areas of Germany, county administrations assume the political responsibility for the regional passenger transport by issuing guidelines for network and timetable design as well as by commissioning bus operators mostly through direct entrustment or as a result of a prior tendering procedure. As a rule of the past, the incumbent transport operator was a subsidiary of the municipal utility group. Offsetting losses incurred for public transportation services was guaranteed by either the profit-pooling entities in the publicly owned group or directly by a planned expenditure of the county's treasury plan.

In the light of the population trends, a still rising household motorization and the process of urbanization of many activity options, and, despite of intermittently rising gasoline prices, the economic environment for the rural bus transport has deteriorated steadily, up to the point of selfmarginalization. With the system-immanent inertia, the decline in patronage was answered merely bureaucratically by scaling down the vehicle kilometres offered. As an isolation of small villages in the course of a network consolidation is politically hardly justifiable, the extent of the scheduled network was formally maintained at the price of a chronical thinning of frequencies besides indispensable, stakeholder-oriented departures. The remaining riders on affected bus routes had to accept fewer frequencies, indirect routings with a low straight-line speed, and timetables directed to the school transport statutes. The postponed, tentative introduction of demand-responsive transport (DRT) services at the current network, merely during evening hours and weekends, was not able to reverse the trend. In the following, the considerable decrease in school enrolment figures has reduced and will further reduce the corresponding source of co-funding as well as its normative effect on network and timetable design. Even with a better financial basis, the bus operating companies need to stabilize the demand on both ends, while seat kilometre costs are rising with a constant area and unchanged concept of operation.

Prior to the EG1370/2007-compliant competitive contracting from 2018 onwards and while facing tighter budgetary restrictions, the local administrations are confronted with the key problems of (i) overcoming the inconsistency between viable service concepts, route network and fleet in order to improve the degree of efficiency under the given new situation and (ii) reviving private out-of-pocket travel demand - on the one hand to satisfy the revenue expectation of possible tenderers, and on the other hand to lower the expected remaining deficits to be covered by the community, that is, by private households in their role as taxpayers.

\section{Previous Work}

A literature review comprised the current state of discussion of public transport in low-demand areas. There is a series of textbooks such as the work by Vuchic [1], covering the fundamentals of public transport and connecting arising economic problems with the technological possibilities to date. The allocation problem of funds for public transport was discovered earlier, profoundly criticizing the principle of equalization of subsidies in space [2]. Sampaio et al. [3] developed operational efficiency measures for public transport as benchmarks for institutional improvement processes. Regaining attractiveness of public transport services in low-demand and structurally less-favoured regions has been a topic of many research reports in Germany and beyond. In their analysis and outlook, Heinze and Kill [4] put emphasis on sustainable funding options. In Germany, the anticipation of aggravating financial problems called for a radical change in thinking and led to a broader, unorthodox discussion in the literature, triggered for example by Canzler and Knie [5]. An extensive number of publications was related to the identification of countermeasures to a declining and increasingly dispersed demand. The predominant direction of thinking is the expansion of flexibility at the supply side rather than a reflection of the profound turnover of customers during one or two decades. Demand-responsive service schemes were systematized [6], surveyed and evaluated at the national level [7, 8], reviewed [9], modelled in their coexistence with existing public transport lines $[10,11]$ and also optimised (e.g. [12]). An earlier piece by Vetter and Haase [13] posed the question of common acceptance limits of flexible service concept and provided new evidence from multivariate data analyses. Other authors focus on the demand side before discussing the implementation of cost-cutting measures. A customer-centric view on the shrinking patronage was suggested by Griskeviciene et al. [14], developing the customer lifetime value approach further. With regard to a revision of the funding schemes, Canzler and Karl [15] proposed a subject-oriented subsidization in the form of mobility vouchers. Notable project results in the design of demand-responsive services according to the needs of elderly residents have recently been published by Vienna University of Technology [16].

\section{Objectives and Methodology}

The research was aimed at the practical decision support of a rural county's public administration and bus operating 
company. The idea for low-demand regions is to depart from the traditional object-oriented strategic planning in ubiquitous central-place grids and the traditional allotment of public funding. In contrast to this, elements of a customer-centric approach and respective data prerequisites shall be created for the years to come. The course of investigation is depicted in Fig. 1.

Based on a literature review and an extraction of critical relationships, a prototypical model of a county's transport demand and supply side is formulated and later instantiated with the findings and a synopsis of quantity structures from recent county-specific case studies.

To understand the problem dimensions and compare the situation at hand, four rural counties and their bus networks-situated in three German federal states-were analysed in terms of their physical and economic geography, travel demand, operating costs, ticket revenues - to substantiate a general year-2025 scenario, as well as to identify uncertainties in market knowledge. For reasons of data confidentiality, the site-specific database was transformed into anonymized form, not providing further site details.

Policy recommendations towards a better market coverage are given by guidelines for small bus operators, i.e. $<5 \mathrm{mn}$ vehicle-km per annum, and will be further illustrated by five model projects.

\section{Results}

\section{Formalization of Public Bus System}

In the following it is demonstrated how decision-relevant indicators were derived from the data available. For the nomenclatures of symbols used see "Appendix".

Figure 2 displays the model for demonstration and calculation of economic relationships at county level. The investigation area is subdivided by a zonal system aligned with the local administrative units-with trip origins indexed by $i$ and destinations by $j$. The public transport supply is represented by a set $\{r\}$ of bus routes. The operator's products comprise five types $\tau$ of bus routes: Scheduled regional "integrated" routes, scheduled urban "integrated" routes-both with service obligation school students (ISV), freely contracted school transport routes (FSV), the range of demand responsive transport (DRT) schemes, and extra tour services (to be excluded in the following). The demand side is grouped into three segments-the trip purpose "school trip", "work trips", and all other purposes. The reconstructed trip count $T$ is the sum of route-related trip count $T_{r}$, adjusted with a correction factor $\hat{\sigma}_{0}$ due to occurring transfers, and estimated by using

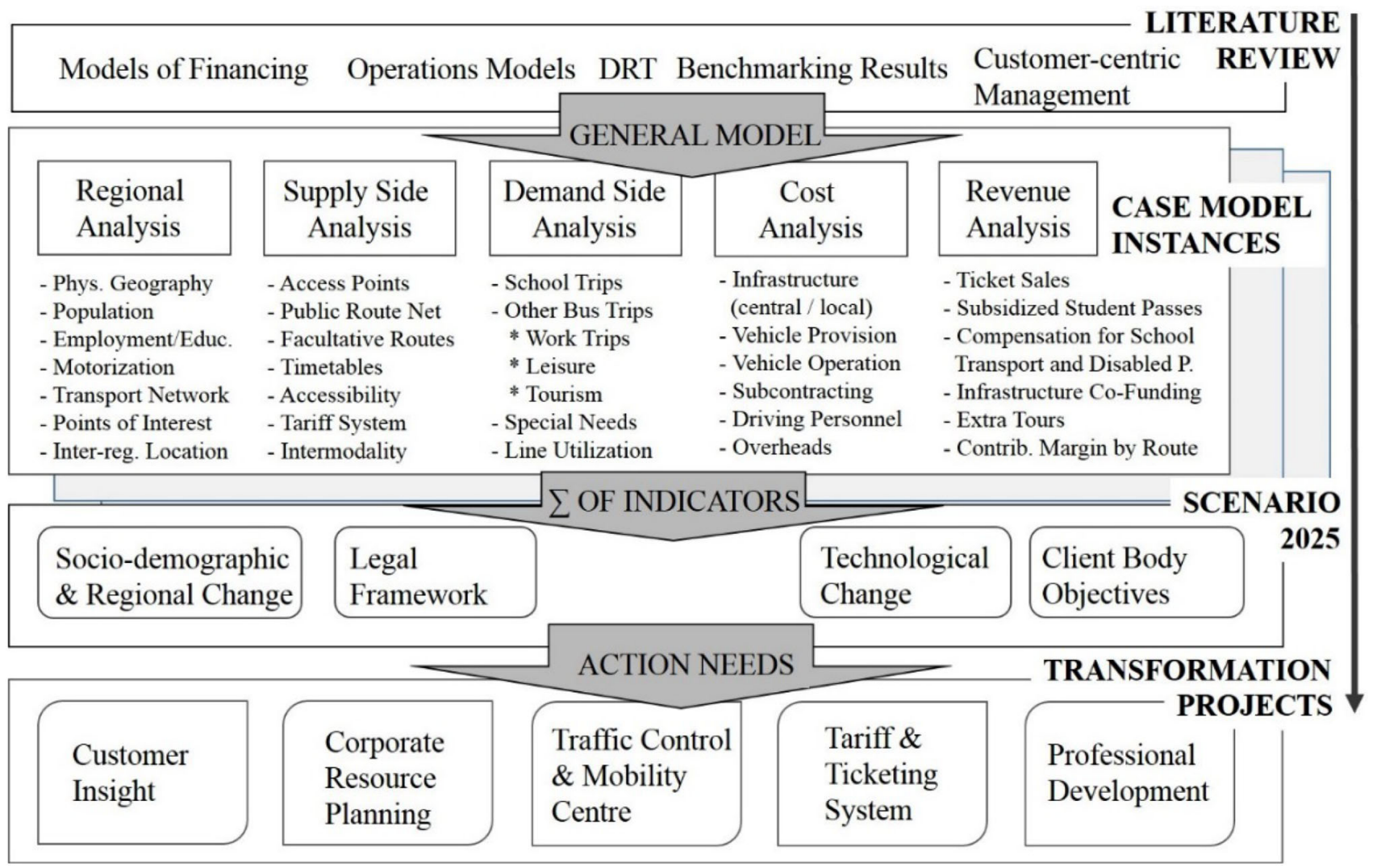

Fig. 1 Study methodology [Source: Own representation] 


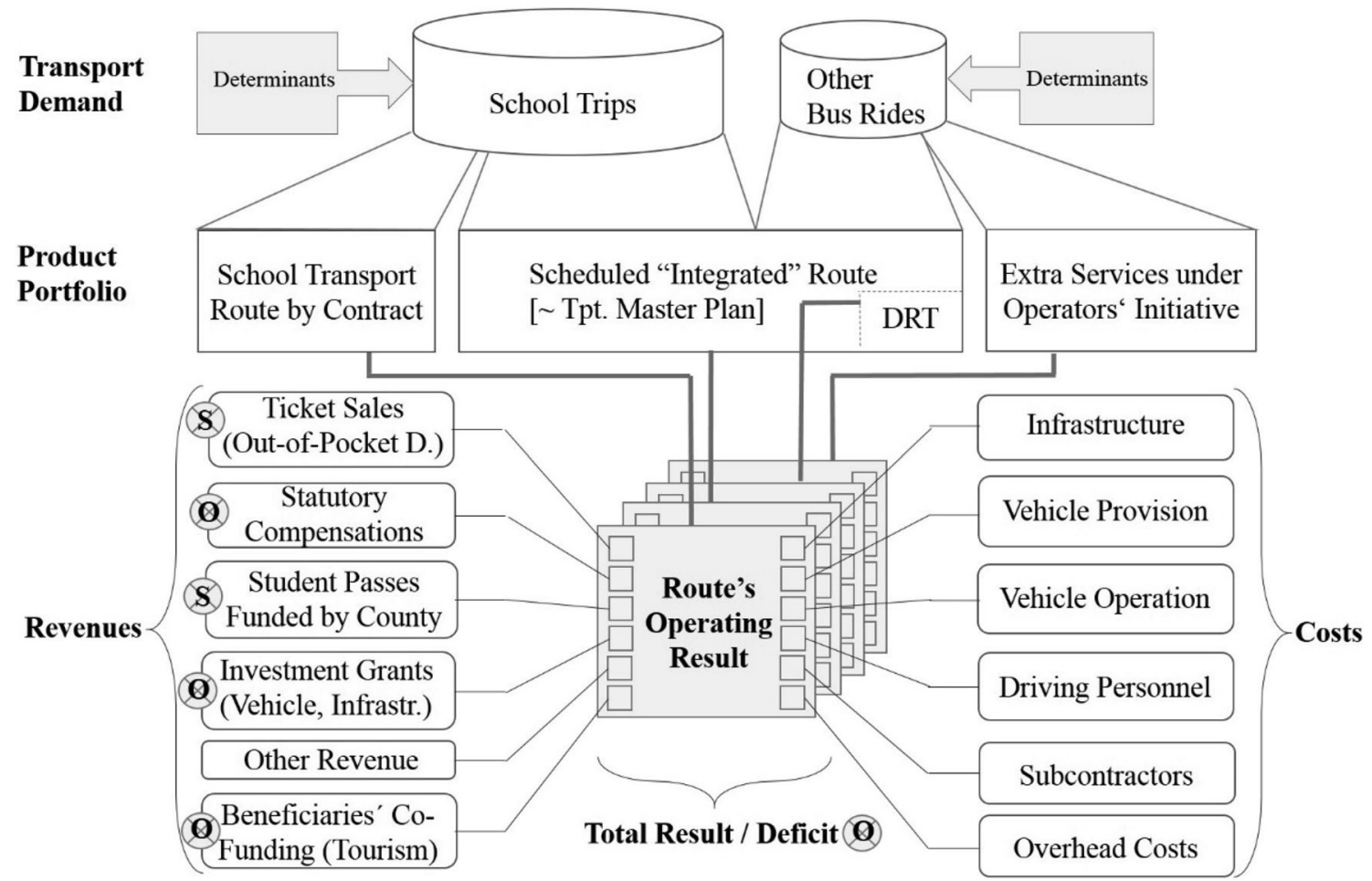

Fig. 2 Drivers of costs and revenues from operators' perspective-differentiated by subject- (S) or object-oriented (O) subsidization [Source: Own representation]

- a lower bound for the basic mobility level, derived from detailed regional structural data (i.e. a homebased trip matrix by origin-specific headcount to the destination-specific number of workplaces $B$, school and training facility capacity $A$, and other trip opportunities $G$, with trip purpose-specific modal splits $m-$ taken from recent household surveys, and by the help of a simplified assignment scheme of O-D trips to routes $\delta_{i, j, r}$ (I: inhabitants, $\hat{\beta}$ : parameter)

- an upper bound, obtained from status quo ticket sales $S_{r, f}$ by route $r$ and fare type $f$ and empirical grossing-up factors $\hat{\sigma}_{f}$ according to the users' behaviour:

$$
\begin{aligned}
& \sum_{i, j}\left(2 B_{i, j} \cdot \hat{m}_{i, j}^{\text {(Work })}+2 A_{i, j} \cdot \hat{m}_{i, j}^{(\text {School })}+\frac{\hat{\beta} \cdot I_{i} \cdot G_{j}}{\sum_{j^{\prime}} G_{j^{\prime}}}\right) \cdot \delta_{i, j, r} \leq \hat{T} \\
& =\hat{\sigma}_{0} \cdot \sum_{r} \hat{T}_{r} \leq \hat{\sigma}_{0} \cdot \sum_{r} S_{r, f} \cdot \hat{\sigma}_{f}
\end{aligned}
$$

Note that, for better clarity, the time dependency index $t$ of the variables is generally omitted.

The routes' operating results or deficits $\Delta_{r}$ are the costs less revenues, each categorized into six items. The total costs of the public transport system $C_{\sum}$ can described by the sum of costs of six cost categories. External costs caused by the bus operations were excluded here. The infrastructure costs $C_{\text {Inf }}$ refer to depots, maintenance facilities, and all bus stops.

$C_{\Sigma}=C_{\text {Inf }}+C_{V e h P}+C_{V e h O}+C_{D P e r s}+C_{S u b}+C_{O v}$

Vehicle provision costs $C_{V e h P}$, vehicle operation cost $C_{V e h O}$, driving personnel cost $C_{\text {DPers }}$, and subcontractor cost $C_{\text {Sub }}$ are modelled specifically by routes $r$ - as a sum of a constant amount $b_{r}$, a multiple of the vehicle-kilometric performance $V_{r}$, and a multiple of the hours of operation $h_{r}$. The unit cost multipliers $\alpha$ are differentiated by the route type $\tau(r)$-if existing ("integrated" scheduled urban route, "integrated" scheduled regional route, exclusive school transport route by contract, DRT routes, and extra tours) as well as the demanded seating capacity $K_{r}$ by route $r$.

$$
\begin{aligned}
& C_{V e h P}+C_{V e h O}+C_{D P e r s}+C_{S u b} \\
& \quad=\sum_{r}\left(\alpha_{0}(\tau(r)) \cdot b_{r}+\alpha_{k}\left(\tau(r), K_{r}\right) \cdot V_{r}+\alpha_{h}\left(\tau(r), K_{r}\right) \cdot h_{r}\right)
\end{aligned}
$$

Expenditures $E$ covered by users $(U)$, federal funds $(F)$, federal state $(S)$, county $(C)$ and external beneficiaries $(B)$ sum up to the operator $(O)$ revenues $R^{(O)}$.

$R^{(O)}=E^{(U)}+E^{(F)}+E^{(S)}+E^{(C)}+E^{(B)}$

The effective user expenditures are modelled by the sum over the range of fare types and routes of products of the 
price-dependent ticket sales from tickets and unit tickets prices depending on the average trip distance $d_{r, f}$, diminished by tax allowance $R$ for work trips.

$E^{(U)}=\sum_{f} \sum_{r} S_{r, f}\left(p_{f}\right) \cdot p_{f}\left(\bar{d}_{r, f}\right)-R_{T A}$

As depicted in Fig. 2, bus users benefit from a mixture of object- and subject-oriented subsidization. Subject-orientation is so far restricted to those entitled to a fare reduction: The county administration covers the lost revenues for free-of-charge student passes $(S P)$, special discounts for the elderly $(S D)$ and free-of-charge transport of disabled persons $(D P)$ - subsequently also the remaining deficit of revenues vs. expenditures.

$E^{(C)}=R_{S P}^{(O)}+R_{S D}^{(O)}+R_{D P}^{(O)}\left(+\Delta^{(O)}\right)$

In accordance with the national legislation $(\$ 45 \mathrm{a}$ PBefG), the federal state compensates for half of the gap between the revenues from school transport and product of the acknowledged unit costs value $c$ (per person-kilometre) and the school transport performance $\Pi^{(S T)}$ of scheduled "integrated" routes only. The school transport performance is determined by route-related student passes and the average route-related trip distance. In addition, vehicle procurement is co-funded by a share of $\phi$, if the state's guidelines (e.g. low-floor technology) are met.

$$
\begin{aligned}
E^{(S)} & =\frac{1}{2}\left(\bar{c} \cdot \Pi^{(S T)}-R_{S T}\right)+\phi \cdot C_{V e h P} \text { with } \Pi^{(S T)} \\
& =\left.\sum_{r} A_{r} \cdot \bar{d}_{r, S T}\right|_{\tau(r)=\text { sched }}, 0 \leq \phi<1
\end{aligned}
$$

The federal government runs a transport investment aid programme to co-fund the local infrastructure renewal and extension by a proportion $\gamma$. Besides the effective reduction in fares, the tax allowance for commuters has a neutral effect on the operator, decreases in the users' contribution to the national revenue by $R_{T A} . E^{(F)}$ is therefore expressed as

$E^{(F)}=\gamma \cdot C_{\text {Inf }}+R_{T A}, \quad 0 \leq \gamma<1$.

The remaining deficit of the operator, to be covered by the county, becomes

$$
\begin{aligned}
\Delta^{(O)}= & C_{\Sigma}-R^{(O)}=(1-\gamma) \cdot C_{I n f}+(1-\phi) \cdot C_{\text {VehP }} \\
& +C_{\text {VehO }}+C_{\text {Pers }}+C_{S u b}+C_{O v} \\
& -E^{(U)}-\left.\frac{1}{2}\left(\bar{c} \cdot \Pi_{S T}-R_{S T}\right)\right|_{\tau=s c h e d} \\
& -R_{S P}^{(O)}-R_{S D}^{(O)}-E^{(B)}
\end{aligned} .
$$

Finally, the customer base, comprising the patronage $Q^{(P)}$ of frequent users and a number of casual users $Q^{(C)}$, is established and related to the county's population size $I$.
The estimated size of the patronage, subdivided into school students $Q^{(S)}$, paying resident customers $Q^{(J)}$ and paying external users $Q^{(E)}$, was established from the number of children participating in school transport as well as subscriber figures of monthly/weekly passes and their usage behaviour $\sigma_{f}$, with a route-related correction factor $\sigma_{0, r}$ considered for multi-route usage

$$
\begin{aligned}
Q^{(P)} & =\sum_{r}\left(Q_{r}^{(S)}+Q_{r}^{(J)}+Q_{r}^{(E)}\right) \\
& =\sum_{r} Q_{r}^{(S)}+\sigma_{0, r} \cdot \sum_{f^{\prime}} S_{r \cdot f^{\prime}} / \hat{\sigma}_{f^{\prime}} .
\end{aligned}
$$

\section{Findings for Case Model Instances}

The above described model was specified by proprietary supply and demand data of four German counties which are particularly affected by the demographic change. The ranges of selected indicators, derived and compiled from respective case studies conducted between 2013 and 2015, are summarized in Table 1. The revenue vehicle-kilometre of rural counties are generally comparable to the national benchmarks [17]. A typical transport model instance has the spatial resolution of 70 traffic cells $(i / j)$.

Additional analyses were conducted: the population density within the counties varies between factor 10 and 17. The agglomeration of the population in town largely corresponds to a Pareto distribution with $k=3$ and leads to typical concentration measures of $C R_{3}=.41$ and $H I>.3$. The obtained regression line for the share of work commuters beyond the community boundaries as vs. logarithmic population size $I$ is

$\sum_{j \neq i} T_{i j}^{(\text {Work })} / \sum_{j} T_{i j}^{(\text {Work })}=-.88 \ln I_{i}+1.4793$.

The larger a community, the lower is the proportion of out-commuting. The high asymmetry of trips between rural and urban zones can be demonstrated by the obtained regression equation for the ratio of destination vs. origin traffic volume versus the logarithm of the population size

$\sum_{i} T_{i j}^{(\text {Work })} / \sum_{j} T_{i j}^{(\text {Work })}=.1967 \ln I_{i}-.7049$.

One exemplary operators' networks comprise approximately 60 routes $r$ (15 urban and 45 rural). However, further timetable analyses revealed that a rural route has three to four sub-routes at average. The fact that several of the sub-routes are circuitous and will be served without a regular pattern implies low air-line speeds along with a puzzling complexity level from the users' viewpoint. In contrast to this, the number of departures per route is low-on average there are 8.7 each direction Mon-Fri. One quarter of the routes has only two daily 
Table 1 Findings for indicators' numerical ranges (Source: Own computation)

\begin{tabular}{|c|c|c|c|}
\hline $\begin{array}{l}\text { Average age annual change rate in } \\
\text { population } I[\%] 10 \mathrm{Y}\end{array}$ & $-1.6 \ldots-0.9$ & $\begin{array}{l}\text { Unit cost } c \text { for compensation of school } \\
\text { transport }[\mathrm{US}-\$ / \mathrm{Pkm}]\end{array}$ & $0.12 \ldots 0.16$ \\
\hline $\begin{array}{l}\text { County's population density in rural/urban } \\
\text { units }\left[\mathrm{P} / \mathrm{km}^{2}\right]\end{array}$ & $20 \ldots 35 / 300 \ldots 350$ & $\begin{array}{l}\text { Annual expenditures (incl. those of users) } \\
\text { per inhabitant [US-\$] }\end{array}$ & $89 \ldots 99$ \\
\hline $\begin{array}{l}\text { Average annual change rate in \# of school } \\
\text { students [\%] } 10 \mathrm{Y}\end{array}$ & $-5.4 \ldots-3.3$ & $\begin{array}{l}\text { Annual expenditures (incl. those of users) } \\
\text { per Pkm [US-\$/Pkm] }\end{array}$ & $2.47 \ldots 2.93$ \\
\hline $\begin{array}{l}\text { Proportion of employed persons to total } \\
\text { population } B / I[\%]\end{array}$ & $33 \ldots 39$ & Proportion out-of-pocket cost vs. total costs [\%] & $10.2 \ldots 16.9$ \\
\hline $\begin{array}{l}\text { Proportion of school students and } \\
\text { trainees to population } A / I[\%]\end{array}$ & $8.5 \ldots 11.8$ & Proportion out-of-pocket cost/avg. mobility expenditures [\%] & $0.8 \ldots 0.9$ \\
\hline $\begin{array}{l}\text { Revenue vehicle-km vs. population } \\
{[\mathrm{km} \text { per capita }]}\end{array}$ & $33.8 \ldots 36.1$ & $\begin{array}{l}\text { Avg. annual cost of frequent user (adult)/household's } \\
\text { average mobility expenditures [\%] }\end{array}$ & $9.5 \ldots 10.9$ \\
\hline $\begin{array}{l}\text { Annual bus trips vs. population } \\
\text { [bus trips per capita] }\end{array}$ & $14.6 \ldots 27.3$ & Average current deficits $\Delta$ vs. total operation $\operatorname{cost} C^{(O)}[\%]$ & $38.0 \ldots 47.8$ \\
\hline $\begin{array}{l}\text { Annual bus trips vs. population \school tpt. } \\
\text { (school students) }\end{array}$ & $1.4 \ldots 11.1$ & $\begin{array}{l}\text { Extrapolated deficit vs. ttl. cost } 2025 \text { "business } \\
\text { as usual" [\%] }\end{array}$ & $49 \ldots 58.3$ \\
\hline $\begin{array}{l}\text { Average annual decline in bus } \\
\text { demand }[\%] 10 \mathrm{Y}\end{array}$ & $-8.7 \ldots-4.6$ & $\begin{array}{l}\text { Customer base (=frequent and casual users) vs. } \\
\text { population }[\%]\end{array}$ & $3.9 \ldots 7.8$ \\
\hline $\begin{array}{l}\text { Public transport modal share-all trip } \\
\text { purposes } \bar{m}[\%]\end{array}$ & $0.3 \ldots 2.2$ & Annual tax allowance vs. otal population $R_{T A} / I[€]$ & 0.38 \\
\hline $\begin{array}{l}\text { Urban and regional bus modal share-all } \\
\text { trip purposes } \bar{m}[\%]\end{array}$ & $0.1 \ldots 2.1$ & Annual tax allowance vs. patronage [US- $\$$ p.a. per capita] & 73.8 \\
\hline $\begin{array}{l}\text { Urban and regional bus modal share, } \\
\text { school tpt. } \bar{m}^{(\text {School })}[\%]\end{array}$ & $39 \ldots 43$ & $\begin{array}{l}\text { Patronage } Q^{(J)}+Q^{(E)} \text { urban and regional (excluding school } \\
\text { transport) vs. population [\%] }\end{array}$ & $0.4 \ldots 0.9$ \\
\hline $\begin{array}{l}\text { Regional bus modal share work trips } \\
\bar{m}^{(\text {Work })}[\%]\end{array}$ & $0.1 \ldots 0.7$ & $\begin{array}{l}\text { Patronage headcount } Q^{(J)}+Q^{(E)} \text { regional bus } \\
\text { vs. population [\%] }\end{array}$ & $0.3 \ldots 0.5$ \\
\hline
\end{tabular}

departures per direction. Exemplary bus networks encountered were still quite dense. On average, there was one bus stop for a 2.5 square kilometres area (or one bus stop per 250-280 inhabitants). About one-third of the bus stops are located in medium-level centre towns, with correspondingly shorter access and a multiple of residents in the catchment area. Notably, the patronage per bus stops does not differ to the same extent. The mean count of frequent riders per bus stop among school students is 9.9, but only 2.0 for rural zones and 2.75 for urban zones, respectively. On average, $43 \%$ of the route length were used, suggesting a good conformity with the mobility needs in general.

The seating capacity of the vast vehicle fleet conforms to the needs of the school transport, but is often inadequately high. The companies are already concerned with a fleet exchange. However, the downsizing does not lower the unit costs proportionate to the loss in capacity.

With regard to ticket revenues, the tariff systems were examined. The assortment of tickets exceeds 40 different types. With an average of 17 fare types per route it is rarely exhausted. Surprisingly, the routes' unit revenues (US-\$/ $\mathrm{Pkm}$ ) positively depend on the share of integrated school transport. Short (contracted) school routes are among the most 'profitable ones.

\section{Scenario for $\mathbf{2 0 2 5}$}

The scenario 2025 serves as the projection of the developments at a ten-year horizon and bridges the gap to the transformation agenda. A compilation of the assumed trends in brief, categorized into the four areas (a) sociodemographic changes, (b) changes in the legal framework, (c) technological trends, and (d) client body target setting, is given in Table 2 .

On the one hand, it becomes clear that a laissez-faire attitude would adversely affect the key economic figures. The foreseeable austerity measures and dictated, unchangeable rises in unit cost levels bear further risks for the local operator.

On the other hand, opportunities arise from an unfolding sense of urgency by the client body administration-away from the former 'Keep it coming!', the presumably larger operation areas, as well as new technological means beneficially for cost reduction, to reach new customer segments and creating customer value by product innovations. 


\section{Conclusions}

This empirical study traces the picture of a regional public transport in the retreat. The stagnation can be placed in the wider context of long-term transitions in advanced economies (with future relevance for several developing countries!) [18], but also be interpreted as the inability of mastering the opportunities of a smaller, but wealthier, more educated, digitally connected, and of course older client base up to now.

In the previous sections, a structuration of the problem, a formalization of a county's bus operations, the compilation of critical indicators obtained from modelled quantity structures of different counties, in conjunction with a scenario for 2025 were presented. The findings provide the basis for policy recommendation of a paradigm shift towards customer centricity. The pursued customer-centric approach differs from the traditional supply side-oriented institutional thinking. Instead, it focuses on the retention of the shrinking customer base, the extension of the range of services used per customer, as well as the purposeful new customer acquisition. The findings give rise to the following critical reflections and conclusions on action needs:

(i) A shortcoming noticed in the course of this review is the data availability at the disaggregated level. (For example: Taking the age cohort, that is according to survey data $[19,20]$ much more open for public transports than in the past-who of the school students remain bus customers after their graduation, whereas the aggregate market share differs between the demand segments by at least factor 20?) While the supply side is widely documented and implemented for the operations control centre software, there is much uncertainty for planners on the other side. Personalized

Table 2 Set of assumptions for a "Scenario 2025" (Source: Own representation)

\begin{tabular}{|c|c|c|}
\hline Area & Prospective Effect & Description of Consequences \\
\hline \multirow[t]{6}{*}{$\begin{array}{l}\text { (a) Socio-demo- } \\
\text { graphic } \\
\text { Change }\end{array}$} & $\begin{array}{l}\text { Shrinking Population/ageing } \\
\text { Population }\end{array}$ & $\begin{array}{l}\text { continued decline in transport demand } \\
\text { shift to older, (in part) mobility-restricted riders, retirement from customer base without } \\
\text { replacement }\end{array}$ \\
\hline & Declining Household Size & decreasing trip party size, unbundling of trip chain \\
\hline & Administrative Reforms & centralization, merger of rural counties, longer trip distances to higher-order central places \\
\hline & Reduced Employment & decline in work mobility \\
\hline & $\begin{array}{l}\text { Lower Absolute School } \\
\text { Enrolment Figures }\end{array}$ & decline in school mobility, centralization of school system, longer access/egress distances \\
\hline & Labour Market & centralization, larger commuting distances \\
\hline \multirow[t]{8}{*}{$\begin{array}{l}\text { (b) Legal } \\
\text { Framework }\end{array}$} & Competition Policy & $\begin{array}{l}\text { uneconomic parallel services between rail and bus avoided } \rightarrow \text { alignment of detrimental } \\
\text { subsidization }\end{array}$ \\
\hline & & public tendering of transport services according to EG 1370/2007 guideline \\
\hline & Subsidization Scheme & commuter tax allowance to remain unchanged \\
\hline & & $\begin{array}{l}\text { uncertain future of federal and federal state level funding for public transport and its } \\
\text { allocation }\end{array}$ \\
\hline & School Transport Statute & $\begin{array}{l}\text { education district plan, travel time limits by age group, min. vehicle seating capacity } \\
\text { prescribed, usually no transfers allowed for school children }\end{array}$ \\
\hline & Minimum Wage Act & rise in bus driver cost and renegotiation by subcontractors expected \\
\hline & Paratransit Operations & $\begin{array}{l}\text { legal basis missing, only formally licenced operators and fixed routings admitted by } \\
\text { default }\end{array}$ \\
\hline & Barrier Freedom & $\begin{array}{l}\text { legal obligation from 2021, from now only low-floor vehicles to be co-funded, no more } \\
\text { "dual use" }\end{array}$ \\
\hline \multirow{3}{*}{$\begin{array}{r}\text { (c) Techno- } \\
\text { logical } \\
\text { Trends }\end{array}$} & $\begin{array}{l}\text { Interconnectedness/Customer } \\
\text { Data }\end{array}$ & $\begin{array}{l}\text { penetration of mobile communication technology, smartcard multi-modal ticketing, } \\
a \mathrm{CRM} / \text { 'big data' capabilities }\end{array}$ \\
\hline & Vehicle Technology & $\begin{array}{l}\text { resource efficiency, emission standards EURO- } 6 \text {, } \\
\text { alternative drives available/decreasing capital cost }\end{array}$ \\
\hline & Design for All Solutions & accessible bus stops and transfer points required \\
\hline \multirow{4}{*}{$\begin{array}{l}\text { (d) Client Body } \\
\text { Objectives }\end{array}$} & Services of Public Interest & minimum accessibility standards within central-place grids \\
\hline & Quality Standards & vehicle characteristics, service frequency, reliability \\
\hline & Regional Development & strengthening of regional economy, development of incoming tourism \\
\hline & Budget Restrictions & austerity policy: deficit targets relative to total cost \\
\hline
\end{tabular}


customer databases, with the exception of the school student registries, are neither established nor deployed for corporate planning task. Missing customer insight, the closeness of managerial and political decision levels, imposing fear of the political viability to some extent have prevented the decision makers from initiating processes of change.

(ii) The initial hypothesis of a very small customer base is applicable: It was established that the demand side is sustained by a few thousand school students and just a few hundred monthly pass holders per $100 \mathrm{k}$ inhabitants-with both figures exhibiting a downward trend. Disaggregating the customer base further by the bus routes, the scheduled network planning encounters the limits of applicability. Arguably, the public transport system's distributive justice among the county's residents is in question. Also with a better financial situation of municipalities, the patronage becomes the limiting factor. To preserve the public transport supply under such circumstances, the operator needs a new approach to determine the extent of the long-term viable network and consistent tariffs.

(iii) The tariff systems are far too complex, especially in relation to the customer base. Fares are route specific, yet only in few cases covering the route network and intermodal transfer options to regional railways and interconnected mobility services for access and egress. The non-integrated tariff system is a relevant entrance barrier for potential users. Since the out-of-pockets users' contributions are very low compared to an average households' mobility spending, the expenditures are not fairly reflected. Even if a premium amount for using eco-friendly modes is taken into account, this ratio suggests a review of pricing under the aspects of the individual willingness-to-pay depending on service features, and secondly related to operating costs. With the high unit costs in sparsely populated regions at hand, the often-proposed fare reductions or even free-ofcharge services are setting wrong incentives and will thus undermine the entire transport system for the given circumstances.

(iv) Conceptualising the objective of balanced percapita user benefits of considerable public funds for both residents and visitors of the county implies a bipartition of the set of existing routes into a fast scheduled basic-interval route network and non-scheduled, less time critical demandresponsive/contracted routes. Out of the range of proven practices, the appropriate DRT schemes need to be selected and applied for a necessary fleet rollover.

Table 3 Overview of transformation projects (Source: Own representation)

\begin{tabular}{|c|c|c|}
\hline Project name & Short description & $\begin{array}{l}\text { Participants involved/estimated resources } \\
\text { (person-months, PM) }\end{array}$ \\
\hline I "Customer insight" & $\begin{array}{l}\text { Passenger counting (general patronage, school students, disabled } \\
\text { persons) in combination with comprehensive user and non-user survey, } \\
\text { analytic database and report design, descriptive statistics and multi- } \\
\text { variate methods }\end{array}$ & $\begin{array}{l}\text { Bus operator, county administration, } \\
\text { market research, scientific advisor/4-5 }\end{array}$ \\
\hline $\begin{array}{l}\text { II "Corporate resource } \\
\text { strategy" }\end{array}$ & $\begin{array}{l}\text { Design of a long-term 'targeted timetable' } \rightarrow \text { fleet structure, depot } \\
\text { location planning, intermodal transfer points to be developed, } \\
\text { assurance of skilled bus driver personnel, selection of market } \\
\text { intelligence and CRM tools, interfaces to smart card ticketing \& } \\
\text { TCMC-see at III }\end{array}$ & $\begin{array}{l}\text { Bus operator, county administration, IT } \\
\text { consultant, scientific advisor/12 }\end{array}$ \\
\hline $\begin{array}{l}\text { III "Traffic control and } \\
\text { mobility centre" } \\
\text { (TCMC) }\end{array}$ & $\begin{array}{l}\text { Pilot organisation and IT solution for non-scheduled mobility services } \\
\text { (DRT fleet, taxi companies, carpooling, bus and car hire, non- } \\
\text { motorized modes) }\end{array}$ & $\begin{array}{l}\text { Bus operator, county administration, IT } \\
\text { consultant, mobility partner firms/14 }\end{array}$ \\
\hline $\begin{array}{l}\text { IV "Tariff system and } \\
\text { ticketing" }\end{array}$ & $\begin{array}{l}\text { Preparation of a tariff association for regional public transit and touristic } \\
\text { purpose } \\
\text {-Design of network tariff structure } \\
\text {-Differentiation urban/rural tariff? } \\
\text {-Smart card ticketing, data interfaces } \\
\text {-Co-funding by bus route benefactors }\end{array}$ & $\begin{array}{l}\text { Bus operator, county administration, } \\
\text { mobility partner firms, scientific } \\
\text { advisor/4 }\end{array}$ \\
\hline $\begin{array}{l}\text { V "Professional } \\
\text { development" }\end{array}$ & $\begin{array}{l}\text { System of training courses for operative and dispositive staff with } \\
\text { exemplary topics: customer data management and CRM, mobility of } \\
\text { elderly/riders with handicap etc. }\end{array}$ & $\begin{array}{l}\text { Bus operator, county administration, } \\
\text { training centre or colla-borating } \\
\text { university/2 }\end{array}$ \\
\hline
\end{tabular}


(v) An organisation development towards a customercentric company [21] is highly recommended. With the increasing importance of stable customer relations, a customer lifetime value-based indicator is useful to individually assess the economic value of existing and future customers-as a base for more customer-centric marketing measures, revenue management, as well as corporate development strategies [22, 23]. Recent best practices for Australia were disseminated by PwC and TTF [24]. The remaining challenge, however, is to adapt the transformation concepts for smaller operators in rural areas. The considerable fixed costs of smart card ticketing and analytic IT needed to create the prerequisites for a customercentric market research such as user multi-product views over time. A pooling with other operators is suggested.

(vi) Finally, the following transformation projects were proposed for a 2 year period and also initiated in part (Table 3).

Acknowledgments The author acknowledges the opportunity to present the research work that forms the basis of this article at the 3rd Conference of the Transportation Research Group of India held at Kolkata (India) from 17 to 20 December 2015.

\section{Appendix}

\section{Nomenclatures of symbols used}

$\mathrm{Z} \quad$ System of zones, serving as origins $i$ and destinations $j$

I Number of inhabitants/zone

$B \quad$ Number of workplaces/zone

A School and training facility capacity/zone

$G \quad$ Capacity of other trip opportunities/zone

$m \quad$ Trip purpose-specific modal splits

$r \quad$ Bus route

$\tau(r) \quad$ Route type

$\delta_{i, j, r} \quad$ Result of model-based assignment of O-D pairs to bus routes $r$

$T, T_{r} \quad$ Bus trips, $\sim$ of route $r$

$K_{r} \quad$ Demanded seating capacity of route $r$ (according to public tpt. plan)

$f \quad$ Fare type

$S_{r . f} \quad$ Ticket sales by route $r$ and fare type $f$

$d_{r, f} \quad$ Average trip distance on route $r$ and fare type $f$

$\alpha, \hat{\beta}, b_{r} \quad$ Functional parameters

$C_{\sum} \quad$ Total costs of the public transport system

$C_{I n f} \quad$ Infrastructure costs

$C_{V e h P} \quad$ Vehicle provision costs
$C_{\text {DPers }} \quad$ Driving personnel cost

$C_{\text {Sub }} \quad$ Subcontractor cost

$h_{r} \quad$ Route hours of operation

$V_{r} \quad$ Vehicle-kilometric performance of route $r$

$\Delta_{r} \quad$ Route-specific deficit/operating profit

$E^{(U)} \quad$ Expenditures covered by users

$E^{(F)} \quad$ Expenditures covered by federal funds

$E^{(S)} \quad$ Expenditures covered by federal state

$E^{(C)} \quad$ Expenditures covered by the county administration

$E^{(B)} \quad$ Expenditures covered by external beneficiaries (B)

$R^{(O)} \quad$ Ticket revenue of bus operator

$R_{T A} \quad$ Personal revenue from tax allowance for work trips

$\sigma_{f} \quad$ Usage multiplier of monthly/weekly passes

$\sigma_{0, r} \quad$ Correction factor for multi-route usage (derived from load pattern)

$\Pi^{(S T)} \quad$ Person-kilometric transport performance of school transport

$\bar{c} \quad$ Unit cost per person-kilometre

$\phi \quad$ Share of co-funding (e.g. vehicle procurement)

$Q^{(U)} \quad$ Customer base: frequent users

$Q^{(C)} \quad$ Customer base: casual users

$Q^{(S)} \quad$ Customer base: school students

$Q^{(J)} \quad$ Customer base: paying residents

$Q^{(E)} \quad$ Customer base: paying non-resident users

\section{References}

1. Vuchic VR (2005) Urban transit: operations, planning and economics. Wiley, Hoboken NJ

2. Evans A (1985) Equalising grants for public transport subsidy. J Transp Econ Policy 19(2):105-138

3. Sampaio BR, Neto OL, Sampaio Y (2008) Efficiency analysis of public transport systems: lessons for institutional planning. Transp Res A 42(3):445-454

4. Heinze GW, Kill HH (2008) Finanzierung des ÖPNV in dünnbesiedelten, struktur-schwachen Regionen: Neue Wege zu einem attraktiven ÖPNV. Abschlussbericht FuE-Vorhaben Nr.70.784/2006/im FoPS des BMVBS, Berlin

5. Canzler W, Knie A (2009) Radikales Umdenken im öffentlichen Landverkehr. Land In Form 3:28-29

6. Transportation Research Board (2004) Operational experiences with flexible transit services, TCRP Synthesis Report, vol 53, Washington DC

7. Böhler-Baedecker S, Jansen U, Kindl A, Reuter C, SchäferSparenberg C, Walter C (2010) Chancen und Risiken flexibler Bedienungsformern im ÖPNV im länd-lichen Raum. BBSR Inf zur Raumentwicklung 7:477-487

8. Davison L, Enoch M, Ryley T, Quddus M, Wang C (2014) A survey of demand responsive transport in great britain. Transp Policy 31:47-54

9. Laws R, Enoch M, Ison S, Potter S (2009) Demand responsive transport: a review of schemes in England and Wales. J Public Transp 12(1):19-37 
10. Neumann A, Nagel K (2013) Passenger agent and paratransit operator reaction to changes of service frequency of a fixed train line. Proc Comput Sci 19:803-808

11. Wang C, Quddus M, Enoch M, Ryley T, Davison L (2014) Multilevel modelling of demand responsive transport (DRT) trips in Greater Manchester based on area-wide socio-economic data. Transportation 41:589-610

12. Crainic TG, Errico F, Malucelli F, Nonato M (2012) Designing the master schedule for demand-adaptive transit systems. Ann Oper Res 194:151-166

13. Vetter T, Haase K (2008) Alternative Bedienformen im ÖPNVAkzeptanzstudie im Landkreis Saalkreis, Diskussionsbeiträge aus dem Institut Wirtschaft und Verkehr Vol 1/2008, Technical University of Dresden (ISSN 1433-626X)

14. Griskeviciene D, Heinitz F, Pataki Nagy D (2009) Irrecoverably shrinking patronages of public transport? A customer lifetime value analysis in conurbations of Erfurt $\&$ Vilnius. In: Proc. 6th TransBaltica, Vilnius, pp 57-62

15. Canzler W, Karl A (2011) Innovativer Landverkehr-Subjektförderung durch Mobilitätsgutscheine. InnoZ Baustein Nr. 9, Berlin

16. Vienna University of Technology (2014) Mobilitätsbedürfnisse einer Alternden Gesellschaft - Optimierung des ÖPNV-Angebots in Wiener Randlagen mittels Alternativer Bedienformen (AGORA), Final Project Report, Vienna
17. Bremische Bürgerschaft (2015) Vorlage 18/374 L Produktplan Umwelt-Bau-Verkehr 68. http://www.hafa.bremischebuergerschaft.de/sixcms/media.php/13/LS_TOP_II\%201\%201_ Benchmarking_Austauschseite.pdf. Accessed 28 Apr 2015

18. Cervellati M, Sunde U, Zimmermann KF (2015) Demographic dynamics and long-run development: perspectives for the secular stagnation debate. In: Proc. IMF Economic Review Conference on "Secular Stagnation, Growth and Real Interest Rates", Florence

19. IFMO (2011) Mobilität junger Menschen im Wandel-multimodaler und weiblicher. Institut für Mobilitätsforschung der BMW AG, München

20. INFAS/DLR (2011) Mobilität in Deutschland, Final Report, Berlin

21. Galbraith JR (2005) Designing the customer-centric organization. Wiley, NY

22. Pfeier PE, Haskins ME, Conroy RM (2005) Customer lifetime value, customer profitability, and the treatment of acquisition spending. J Manag Issues 17(1):11-25

23. Vinod B (2008) The continuing evolution: customer-centric revenue management. J Revenue Pricing Manag 7(2008):27-39

24. PwC/TTF (2007) Improving your commute-lifting customer service in public tr. https://www.pwc.co.uk/en_UK/gx/psrc/pdf/ ttf_improving_your_commute_july_2011.pdf. Accessed 8 May 2015 